\title{
SINTESIS MIKRO SELULOSA BAKTERI SEBAGAI PENGUAT (REINFORCEMENT) PADA KOMPOSIT BIOPLASTIK DENGAN MATRIKS PVA (POLYVINYL ALCOHOL)
}

\author{
Maryam $^{1}$, Dedy Rahmad², dan Yunizurwan ${ }^{1}$ \\ 1 Jurusan Teknik Industri Agro, Politeknik ATI Padang \\ 2 Jurusan Teknik Kimia Bahan Nabati, Politeknik ATI Padang \\ Jl. Bungo Pasang, Tabing, Padang, 25171 \\ Email: maryam.atip@gmail.com
}

Received : 20 Juli 2018; revised : 1 Agustus 2018; accepted : 22 Agustus 2019

\begin{abstract}
ABSTRAK
SINTESIS MIKRO SELULOSA BAKTERI SEBAGAI PENGUAT (REINFORCEMENT) PADA KOMPOSIT BIOPLASTIK DENGAN MATRIKS PVA (POLYVINYL ALCOHOL). Permasalahan limbah dari plastik konvensional yang mencemari lingkungan dan tanah perlu dicarikan solusi. Pengembangan plastik biodegradable dengan matriks Polyvinyl Alcohol (PVA) menjadi salah satu solusi. PVA merupakan polimer sintetis yang mudah larut dalam air dan mudah terdegradasi. Kekurangan plastik biodegrdable adalah memiliki karakteristik fisik dan mekanis yang rendah, sehingga perlu ditambahkan penguat (reinforcement). Penguat yang digunakan adalah mikro selulosa bakteri yang mana kandungan selulosanya cukup tinggi dan mudah diperoleh. Metode yang digunakan untuk membuat mikro selulosa bakteri adalah hidrolisis asam klorida pada kondisi $5 \mathrm{M}$, $55{ }^{\circ} \mathrm{C}$ selama 24 jam. Rancangan percobaan yang digunakan adalah rancangan acak lengkap (RAL) dengan perlakuan penambahan penguat mikro selulosa bakteri yang meliputi $0 \%, 2 \%, 6 \%$, dan $10 \%$. Pembuatan plastik biodegradable menggunakan metode casting. Hasil penelitian menunjukkan mikro selulosa bakteri yang diperoleh pada sebaran $535.8 \mathrm{~nm}$ dengan distribusi $97.2 \%$. Komposisi terbaik pada penambahan penguat $2 \%$, dengan kekuatan tarik 15,72 MPa, modulus young $16,3 \mathrm{Gpa}$, dan densitas $0,13 \mathrm{~g} / \mathrm{cm}^{3}$ dengan tingkat degradasi $100 \%$. Kegunaan bioplastik ini disarankan sebagai pengemas cerdas (smart packaging).
\end{abstract}

Kata kunci: Bioplastik, Hidrolisis, PVA, Mikro selulosa bakteri

\begin{abstract}
MICRO SYNTHESIS BACTERIA AS A REINFORCEMENT IN BIOPLASTIC COMPOSITES WITH PVA MATRIX (POLYVINYL ALCOHOL). Environmental problem from plastic waste should be reduced and solved. The development of biodegradable plastic from polyvinyl alcohol matrix (PVA) can be a solution to solve it. PVA is a synthetic polymer that is dissolved in water and easy to be degraded. The deficiency of biodegradable plastic is low in physical and mechanical characteristic such as strength, which can be encounter by adding reinforcement material. In this research, casting method was used in producing biodegradable plastic. The reinforcement material that was added is micro bacterial cellulose which have high number cellulose and easy to find. The method to produce micro bacterial cellulose was hydrochloric acid hydrolysis in $5 \mathrm{M}, 55^{\circ} \mathrm{C}$ for 24 hours. This method could produce micro bacterial cellulose in the size of 489,9 $\mathrm{nm}$. Experimental design used was complete random by additional reinforcement $0 \%, 2 \%, 6 \%$ and $10 \%$. The result shows that the best composition was $2 \%$ additional reinforcement with 15,72 MPa tensile strength, 16,3 GPa modulus young and density 0,13 $\mathrm{g} / \mathrm{cm}^{3}$ and also $100 \%$ degraded. This biodegradable plastic should be used as smart packaging.
\end{abstract}

Key word: Bioplastic, Hydrolysis, PVA, Micro bacterial cellulose

\section{PENDAHULUAN}

Penggunaan plastik konvensional akan berdampak pada pencemaran lingkungan dan masalah kesehatan dalam jangka panjang. Plastik konvensional merupakan polimer yang terbuat dari produk olahan minyak bumi. Bahan dasar plastik, yaitu poliolefin dibuat melalui proses polimerisasi (penggabungan) etilen maupun propilen yang merupakan produk hasil pengolahan minyak bumi. Polimer ini memiliki ukuran molekul yang sangat besar dan bersifat inert (tidak mudah bereaksi), berat molekulnya ratusan ribu hingga jutaan, terdegradasi dalam 
waktu ratusan tahun, bahkan ribuan tahun (Kamsiati 2013). Bahan dasar plastik konvensional adalah polietilena (PE), polipropilena (PP), dan polivinil klorida yang bersifat stabil, sukar diuraikan oleh mikroorganisme.

Bahan plastik yang aman bagi kesehatan serta ramah lingkungan perlu dikaji untuk dapat menggantikan plastik konvensional. Berbagai bahan alami, seperti polisakarida (selulosa, pati, kitin), protein (kasein, whey, kolagen) dan lemak. Bahan sintesis yang biodegradable seperti Polyvinyl Alcohol (PVA), poli hidroksi alkanoat $(P H A)$, polylactic acid $(P L A)$ telah dapat digunakan sebagai bahan pembuat plastik biodegradable.

Hal yang menyebabkan PVA banyak digunakan sebagai bahan kemasan alternatif yang menjanjikan karena sifatnya yang sangat baik dalam pembentukan kemasan, tahan terhadap minyak dan lemak, memiliki kekuatan tarik, dan fleksibilitas tinggi. PVA memiliki kompatibilitas yang baik jika ditambahkan filler berupa nanoselulosa sehingga dapat menghasilkan produk komposit yang ramah lingkungan (Roohani 2008). Penelitian pengembangan bioplastik dengan matriks Polyvinyl Alcohol (PVA) dengan filler nanoselulosa dari serat nanas telah dilakukan oleh (Iriani 2015).

Ukuran yang lebih kecil (mikro/nano) bisa meningkatkan luas permukaan partikel sehingga terjadi peningkatan kekuatan komposit. Hal ini juga terkait dengan adanya sifat atau fenomena baru yang muncul jika materi tersebut digunakan pada skala nano akibat perubahan sifat fungsional bahan, terkait dengan perubahan sifat dispersinya (Lin 2009). Penambahan selulosa dalam ukuran mikro yang berasal dari serat, ternyata dapat memperbaiki dan meningkatkan sifat mekanis, sifat barrier, serta kemampuan agregasi dengan partikel lain yang lebih baik. Mikro serat memiliki luas interface yang sangat besar sehingga apabila dikompositkan dan terdistribusi merata akan mengubah mobilitas molekuler dan sifat relaksasi menghasilkan komposit dengan fleksibilitas, kekakuan, dan ketahanan panas serta listrik yang baik.

Sumber serat selulosa bakteri (nata de coco) berpotensi sebagai serat penguat bioplastik karena bahan baku melimpah, murah, dan ramah lingkungan. Studi mendalam terhadap selulosa bakteri untuk berbagai bidang aplikasi sangat diperlukan untuk meningkatkan nilai tambah bagi produk selulosa bakteri dan tidak terbatas pada pemanfaatannya sebagai produk makanan. Selulosa bakteri memiliki kandungan serat selulosa yang tinggi, namun miskin kandungan zat gizi jika dijadikan sumber makanan sehingga bisa dialihkan sebagai bahan baku atau filler bioplastik. Selulosa yang dihasilkan dari bakteri Acetobacter xylinum yang terbentuk memiliki keunggulan yaitu kemurnian tinggi, derajat kristalinitas tinggi, mempunyai kerapatan tinggi, kekuatan tarik tinggi, elastis, dan dapat terdegradasi.

Aplikasi penelitian ini adalah untuk mendesain kemasan pangan berupa nanokomposit yang bisa digunakan sebagai smart packaging. Teknologi pengemasan yang diperkirakan mampu menjawab tantangan inovasi kemasan produk pangan adalah smart packaging yang dapat dikategorikan menjadi dua, yaitu active packaging dan intelligent packaging. Material yang berpotensi besar untuk digunakan dalam pengembangan smart packaging adalah nanokomposit. Komposit terdiri dari matriks polimer (continuos phase) dan filler (discontinuos phase). Nanokomposit dibuat dari penggabungan nanofiller yang memiliki ukuran dimensi nano (1-100 nm) (Honavar 2016). Nanokomposit memiliki keunggulan dapat meningkatkan kualitas daya hambat kemasan terhadap gas, meningkatkan kekuatan kemasan, dan memiliki sifat resisten terhadap panas yang lebih baik dari polimer dan komposit konvensional, serta meningkatkan biodegradasi kemasan (Bratovčić 2015). Material yang bisa digunakan sebagai polimer pada pembuatan polimer nanokomposit adalah selulosa. Selulosa sangat murah dan mudah ditemukan. Selain itu, bahan ini juga ramah lingkungan, mudah didaur ulang, dan tingkat konsumsi energi yang rendah selama pemrosesan. Hal ini membuat selulosa nanofiller sangat menarik untuk dikembangkan sebagai nanokomposit yang murah, ringan, dan berkekuatan tinggi (Sanchez 2012).

Pada saat ini, metode produksi nanoselulosa secara kimia terdiri dari: metode asam, organosolv, pelarut alkali, oksidasi, dan cairan ionik. Berdasarkan literatur, metode asam yang sering digunakan secara luas dapat dilihat pada Tabel 1.

Hidrolisis selulosa yang umum digunakan adalah dengan menggunakan asam kuat. Asam kuat dapat menghilangkan bagian amorf dari suatu rantai selulosa sehingga isolasi pada bagian kristalin selulosa dapat dilakukan. Asamasam kuat yang digunakan dalam hidrolisis asam memang cocok dalam sintesis mikro selulosa. Hasilnya, efek dari perbedaan jenis asam, $\mathrm{pH}$, suhu reaksi, dan waktu reaksi terhadap sumber selulosa merupakan hal yang penting untuk memaksimalkan modifikasi muatan permukaan pada selulosa yang diinginkan. Jenis-jenis asam kuat antara lain asam klorida $(\mathrm{HCl})$, asam nitrat $\left(\mathrm{HNO}_{3}\right)$ dan asam sulfat $\left(\mathrm{H}_{2} \mathrm{SO}_{4}\right)$. 
Beberapa literatur di atas menggunakan asam suflat dan asam krolida dalam hidrolisis selulosa. Peneliti lebih banyak menggunakan asam sulfat. Terdapat beberapa kelemahan penggunaan asam sulfat dalam proses produksi skala besar, yaitu masalah lingkungan dan ketersediaan di pasar. Pada pembuatan mikrokristalin selulosa larutan asam mineral encer yang digunakan adalah asam klorida $(\mathrm{HCl})$, hal ini dikarenakan $\mathrm{HCl}$ memiliki harga yang murah dan mudah diperoleh. Selain itu $\mathrm{HCl}$ memiliki kereaktifan yang lebih baik dalam proses hidrolisis jika dibandingkan dengan asam lainnya seperti asam Nitrat dan $\mathrm{H}_{2} \mathrm{SO}_{4}$ (Edison 2016).

Beberapa penelitian mengenai bioplastik yang telah dilakukan oleh peneliti sebelumnya dapat dilihat pada Tabel 2. Penelitian bioplastik dengan matriks PVA dengan filler nano cellulose fiber (Kakroodi 2014) dan bioplastik dengan matriks PVA dengan filler nanoselulosa serat nanas (Iriani 2015). Dan beberapa penelitian lain seperti bioplastik dengan matriks PLA dan filler precipitated $\mathrm{CaCO}_{3}$ (Baek 2014); bioplastik dengan matriks PCL dan filler $\mathrm{CaCO}_{3}$ nanopartikel; bioplastik dengan matriks nanopartikel pati tapioka (Mulyono 2015); bioplastik dengan matriks pati tapioka dan filler nanopartikel tanah liat (Souza 2012); bioplastik dengan matriks pati lidah buaya dan filler kitosan (Utomo 2013); dan bioplastik dengan matriks pati ubi jalar dan filler selulosa rumput laut (Darni 2011). Berdasarkan hasil review literatur yang dilakukan pada Tabel 1 dan Tabel 2, maka kebaruan dari penelitian ini adalah penggunaan mikro selulosa bakteri sebagai penguat bioplastik dengan matriks PVA. Tujuan penelitian ini adalah mendapatkan serat mikro selulosa bakteri dan mengetahui karakteristik fisik bioplastik dengan matriks polivinil alkohol dan filler mikro selulosa bakteri.

Tabel 1. Bahan baku, metode dan hasil sintesis nanoselulosa

\begin{tabular}{lcccc}
\hline No. & $\begin{array}{c}\text { Metode yang } \\
\text { digunakan }\end{array}$ & Bahan baku & Diameter Serat (L\&d) & Rujukan \\
\hline 1 & Hidrolisis Asam & Mikrokristalin selulosa, asam sulfat & $150-200 \times 10-20 \mathrm{~nm}$ & (Michael 2012)
\end{tabular}

\begin{tabular}{|c|c|c|c|c|}
\hline 2 & Hidrolisis Asam & & $35 \times 115 \mathrm{~nm}$ & (Souza 2012) \\
\hline 3 & Hidrolisis Asam & $\begin{array}{l}\text { Kertas saring Whattman, asam } \\
\text { bromide }\end{array}$ & $100-400 \times 7-8 \mathrm{~nm}$ & (Sadeghifar 2011) \\
\hline 4 & Hidrolisis Asam & $\begin{array}{l}\text { Mikrokristalin selulosa, asam } \\
\text { sulfat, asam klorida, dan air hasil } \\
\text { destilasi }\end{array}$ & $20-90 \mathrm{~nm} \bullet$ & (Wang 2008) \\
\hline 5 & Hidrolisis Asam & Serat bambu, asam sulfat & $100-130 \times 5-8 \mathrm{~nm}$ & (Brito 2012) \\
\hline 6 & Hidrolisis Asam & Limbah katun, asam sulfat & $10-65 \mathrm{~nm} \bullet$ & (Xiong 2012) \\
\hline 7 & Hidrolisis Asam & $\begin{array}{l}\text { Limbah potongan kelapa, asam } \\
\text { sulfat }\end{array}$ & $5-6 \times 58-515 \mathrm{~nm}$ & (Rosa 2010) \\
\hline
\end{tabular}

Tabel 2. Daftar penelitian tentang bioplastik dengan berbagai matriks dan filler

\begin{tabular}{llll}
\hline No & Matriks & Filler (pengisi) & Rujukan \\
\hline 1 & Polivinil Alkohol (PVA) & Nano celulose fibers & (Kakroodi 2014) \\
2 & Polylactic Acid (PLA) & Presipitated CaCO3 & (Baek 2014) \\
3 & Polikaprolakton (PCL)/ kitosan & CaCO3 nanopartikel & (Abdolmohammadi 2012) \\
4 & Pati tapioka (nanopartikel) & Tanpa pengisi & (Mulyono 2015) \\
5 & Pati tapioka & Nanopartikel tanah liat & (Souza 2012) \\
6 & Pati lidah buaya & Kitosan & (Utomo 2013) \\
7 & Polivinil Alkohol (PVA) & Nanoselulosa serat nanas & (Iriani 2015) \\
8 & Pati ubi jalar & Selulosa rumput laut & (Darni 2011) \\
\hline
\end{tabular}




\section{BAHAN DAN METODE}

\section{Bahan}

Bahan yang digunakan adalah air kelapa yang diperoleh dari limbah pengolahan santan dari pasar Tabing, gula pasir, asam asetat (cuka) merk sendok, urea, $\mathrm{HCl}$ merk Merck, PVA bubuk, $\mathrm{NaOH}$ merk Merck, $\mathrm{NaOCl}$ merk Merck, dan kertas saring whatman 41 .

Peralatan yang digunakan dalam SEM (Scan Electron Microscopy) Merk Hitachi 3400 seri $\mathrm{N}$ untuk mendapatkan gambar SEM partikel dan permukaan plastik (ISO/TC 202/SC 4), PSA (Particle Size Analyzer) merk Malvern untuk analisis ukuran selulosa bakteri. Proses pengujian kekuatan tarik dilakukan dengan menggunakan alat Universal Testing Machine (UTM) merk Com-Ten 95T untuk uji tarik bioplastik. Pengujian dilakukan berdasarkan standar ASTM D 882-02 dengan kecepatan $5 \mathrm{~mm} /$ menit ([ASTM] 2002). Peralatan lainnya adalah alat pengujian gugus fungsi dengan Spektroskopi Infra Merah Fourier-Transform (FTIR), ayakan mesh, alat cetak plastik dari kaca yang dirancang oleh peneliti sendiri. Alat pengering freeze drying, spray drying merk Buchi B290, dan pompa vakum.

\section{Metode}

Penelitian ini akan dilaksanakan dengan 3 tahapan yaitu :

Tahap 1. Tahapan ini adalah membuat selulosa bakteri (nata de coco), pengecilan ukuran, dan pengeringan hingga diperoleh selulosa bakteri dalam bentuk serbuk, yaitu diayak dengan ayakan ukuran 100 mesh.

Tahap 2. Tahapan ini adalah melakukan hidrolisis menggunakan $\mathrm{HCl}$ (asam klorida) pada kondisi $5 \mathrm{M} \mathrm{HCl}$, temperatur $55^{\circ} \mathrm{C}, 24$ jam. Setelah itu hasil hidrolisis akan dilakukan penyaringan dengan kertas saring whatman 41 dengan bantuan pompa vakum dan pencucian hingga netral. Mikro selulosa bakteri disimpan dalam bentuk sediaan basah. Proses berikutnya adalah pengeringan dengan spray dryer apabila sediaan disimpan dalam bentuk kering.

Tahap 3. Tahapan ini adalah pembuatan komposit bioplastik dengan metode casting. Pembuatan bioplastik dilakukan dengan cara melarutkan $\mathrm{x} \%(0 \%, 2 \%, 6 \%$, dan $10 \%)$ mikro selulosa bakteri terlebih ke dalam $100 \mathrm{ml}$ akuades ditambah $3 \mathrm{ml}$ gliserol. Mikro selulosa bakteri dapat larut sempurna dengan pengadukan selama kurang lebih 30 menit dengan menggunakan magnetik stirrer. Kemudian ditambahkan PVA sebanyak $10 \mathrm{~g}$ dan dilakukan pengadukan 1 jam dengan dipanaskan $80^{\circ} \mathrm{C}$ sampai $85^{\circ} \mathrm{C}$. Selanjutnya dicetak dengan metode casting dengan alat cetak plastik.

\section{HASIL DAN PEMBAHASAN}

Berdasarkan hasil

pengujian menggunakan alat Universal Testing Machine (UTM) dengan standar ASTM D 882-02 ([ASTM] 2002) terhadap lembaran selulosa bakteri (nata de coco) memiliki tensile strength rata-rata sebesar 380,56 Mpa. Semakin banyak jumlah serat yang terbentuk, maka semakin besar kuat tarik serat tersebut. Nilai modulus young ratarata $18 \mathrm{Gpa}$ dan elongasi $11,3 \%$. Besar densitas serat rata-rata adalah $1,3 \mathrm{~g} / \mathrm{cm}^{3}$. Lapisan selulosa ini sangat kuat, bersifat kaku karena memiliki modulus elastisitas yang tinggi dan regas dengan nilai modulus elongasi yang rendah.

Bakteri selulosa merupakan polimer yang mempunyai struktur supramolekul dan kristalinitas selulosa yang tinggi. Salah satu sifat dari serat bakteri selulosa adalah memiliki porositas yang tinggi dan bersifat hidrofilik serta kemampuan serat dalam menyerap air yang tinggi (swelling). Hasil penelitian menunjukkan bahwa kandungan serat (selulosa) dari bakteri selulosa adalah $0,9 \%$ hingga $1,0 \%$ dari massa total. Kandungan terbesarnya adalah air yang mencapai $99 \%$. Selulosa bakteri yang dihasilkan memiliki nilai kadar air yang tinggi yaitu $98 \%$ (Syamsu 2014). Pemasakan dengan $\mathrm{NaOH} 5 \%$, pada suhu $100^{\circ} \mathrm{C}$ selama 4 jam bertujuan untuk proses pemurnian menghilangkan lemak dan protein dalam selulosa bakteri sehingga diperoleh selulosa murni. Proses hidrolisis menggunakan $\mathrm{HCl}$ telah berhasil mengurangi ukuran serat selulosa bakteri rata-rata $489,9 \mathrm{~nm}$ berdasarkan hasil pengujian PSA seperti pada Gambar 1. Diameter yang dihasilkan dari pengukuran PSA adalah diameter hidrodinamika $(d H)$ yaitu diameter bola pejal yang berdifusi pada kecepatan yang sama dengan partikel yang diukur.

Hidrolisis asam adalah proses utama yang digunakan dalam memproduksi nanokristal selulosa, dimana susunan blok kecil dipisahkan dari serat selulosa. Selulosa terdiri dari daerah amorf dan daerah kristal. Daerah amorf memilik kerapatan yang lebih rendah daripada daerah kristalin, sehingga bila selulosa diberi perlakuan dengan menggunakan asam kuat, daerah amorf akan memecah dan melepaskan daerah kristalin. Sifat nanokristal selulosa bergantung pada berbagai faktor, seperti sumber selulosa, waktu reaksi, suhu, dan jenis asam yang digunakan untuk proses hidrolisis. Asam kuat dapat menghilangkan bagian amorf dari rantai 
selulosa sehingga isolasi pada selulosa kristal dapat dilakukan (Oke 2010).

Hasil pengeringan dengan freeze drying tidak bisa menghasilkan sediaan dalam bentuk kering karena mikro selulosa yang terbentuk berupa gumpalan. Sediaan mikro selulosa bakteri dapat disimpan dalam bentuk basah (2a). Pengeringan dengan spray drying menghasilkan sediaan nano selulosa dalam bentuk serbuk (2b dan 2c). Hasil mikro selulosa bakteri dapat dilihat pada Gambar 2. Hasil pengujian Scanning Electron Microscopy (SEM) mikro selulosa bakteri dapat dilihat pada Gambar 3. Terlihat bahwa mikroselulosa yang dihasilkan memiliki ukuran yang kurang seragam. Sejalan dengan hasil pengujian PSA yang menunjukkan terdapat partikel dengan ukuran 535,8 nm sebanyak 97,2\% dan $5286 \mathrm{~nm}$ sebanyak 2,8\%. Hasil pengujian SEM bioplastik dapat dilihat pada Gambar 4. Berdasarkan Gambar 4 dapat dilihat bahwa mikro selulosa bakteri terdistribusi di dalam matriks PVA, ini berarti bahwa proses pengisian mikroselulosa bakteri ke dalam matriks berjalan dengan baik. Hasil tampilan fisik secara visual plastik dari semua perlakuan dapat dilihat pada Gambar 5 . Ukuran partikel dalam skala nano/mikro memiliki luas permukaan yang lebih besar jika dibandingkan dengan partikel sejenis dalam ukuran besar (Jain 2008) sehingga bisa berikatan kuat dalam matriks. Ukuran partikel selulosa yang halus (mikro) mengakibatkan struktur morfologi yang lebih rapat dalam matriks.

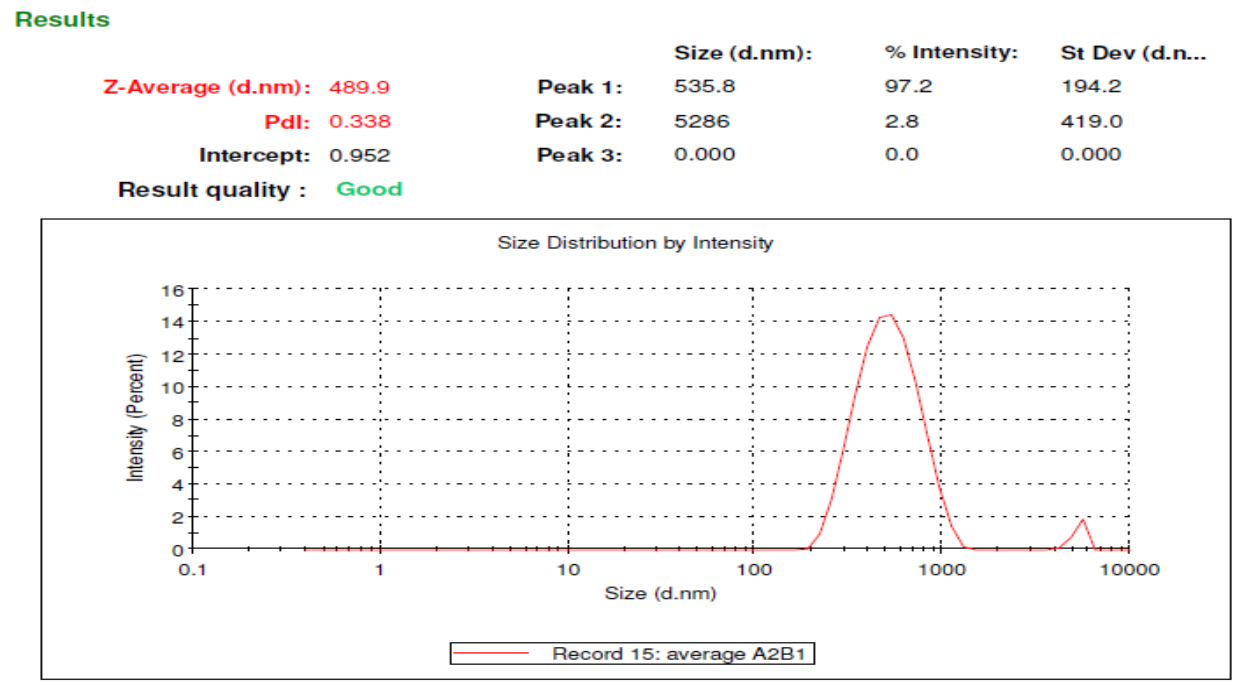

Gambar 1. Hasil Pengujian PSA

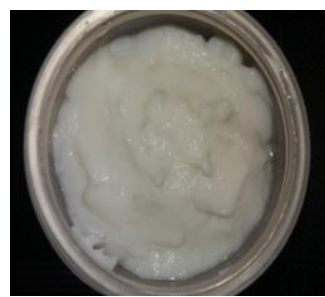

$2 a$

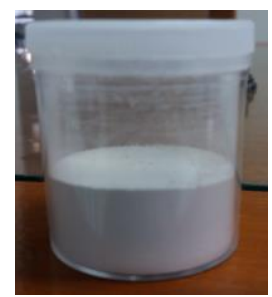

$2 b$

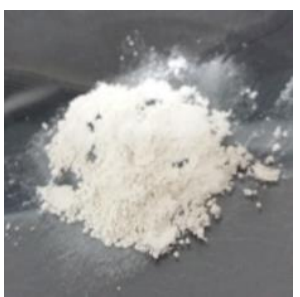

2c

Gambar 2. Mikro selulosa bakteri 


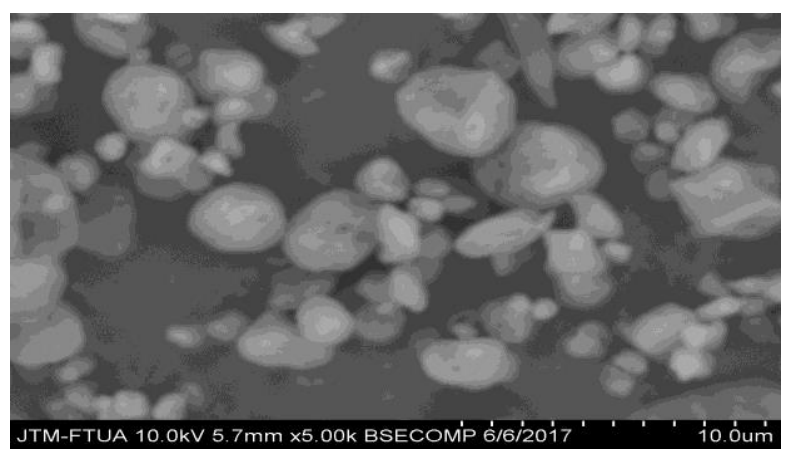

Gambar 3. Hasil SEM nano selulosa bakteri

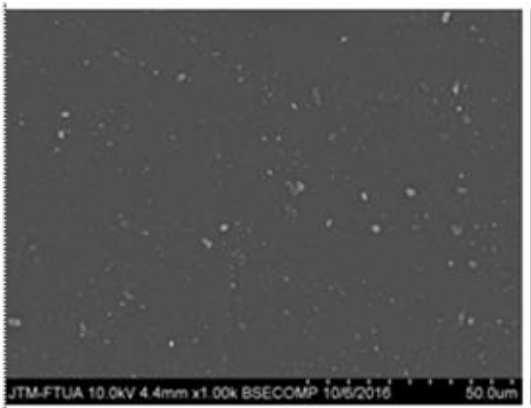

(a)
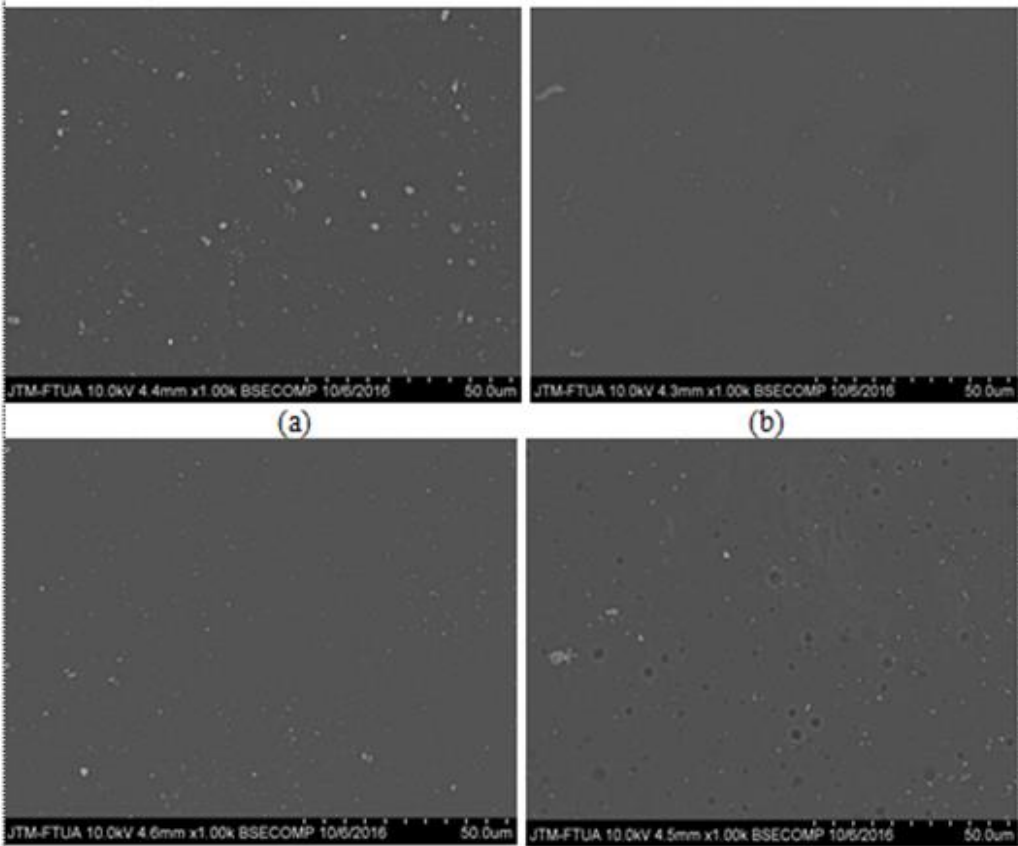

(b)

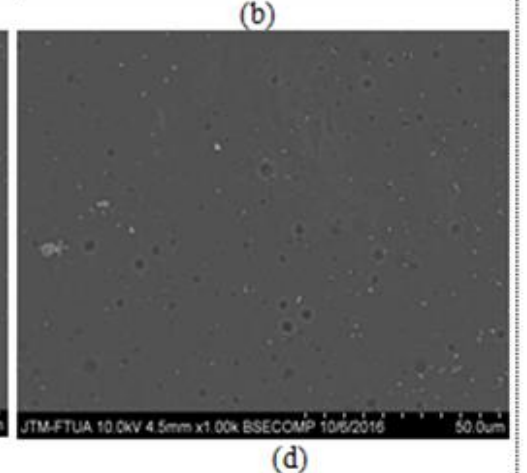

(c)

Gambar 4. Hasil SEM bioplastik dengan penambahan 0\% (a), 2\% (b), 6\% (c) dan 10\%(d)

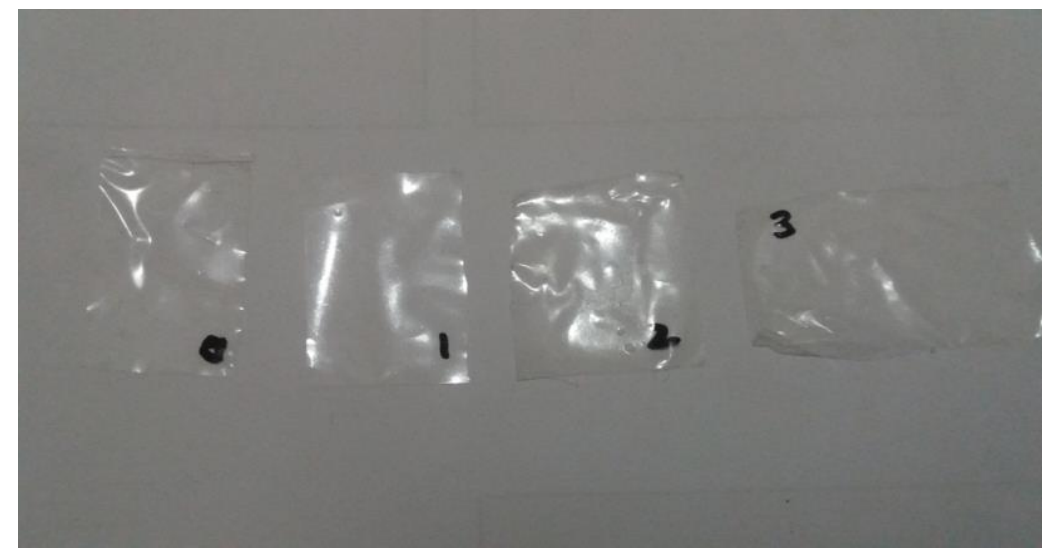

Gambar 5. Hasil tampilan visual bioplastik

Sifat fisik komposit bioplastik dapat diketahui dengan melakukan uji mekanik kuat tarik dengan menggunakan alat uji Ultimate Tensile Strength. Uji ini digunakan untuk mengetahui kekuatan tarik dari lembaran bioplastik sebelum dan setelah menjadi komposit. Pengujian kuat tarik ini dilakukan sesuai dengan ASTM D 882-02. Hasil uji kuat 
tarik bioplastik dari semua perlakuan ditunjukkan dalam Tabel 3. Hasil perlakuan terbaik pada perlakuan $2 \%$ dengan kekuatan tarik 15,72 MPa, modulus young 16,3 GPa dan densitas $0,13 \mathrm{~g} / \mathrm{cm}^{3}$ dengan tingkat degradasi $100 \%$. Penambahan mikro selulosa bakteri secara signifikan meningkatkan kuat tarik (tensile strength) bioplastik tetapi menurunkan nilai elongasi (tensile modulus).

Penambahan selulosa mampu meningkatkan kekuatan tarik film plastik pada variasi tertentu. Selulosa mempunyai rantai polimer yang lurus dan panjang sehingga dapat membuat plastik menjadi lebih kuat. Kadar selulosa yang terlalu banyak akan menyebabkan film plastik semakin tidak homogen. Ketidakhomogenan ini berakibat pada tidak sempurnanya blending yang terjadi, sehingga ikatan yang terjadi antara pati-selulosa dan gliserol tidak kuat. Ikatan antar komponen penyusun ini sangat berpengaruh pada kekuatan tarik film plastik (Sultyo 2012).

Uji FTIR (Fourier Transform Infrared Spectroscopy) sebagai analisis yang dilakukan untuk menentukan gugus fungsi pada polimer dapat dilihat pada Gambar 6. Hasil identifikasi gugus fungsi pada film bioplastik yang terbentuk pada spektrum serapan IR merupakan gabungan dari gugus fungsi spesifik yang terdapat pada masing-masing komponen penyusun bioplastik tersebut. Bioplastik yang didapat merupakan bioplastik yang dihasilkan melalui proses pencampuran (blending), hal ini dapat dilihat karena tidak ditemukan gugus fungsi baru. Selain itu, dapat disimpulkan pula bahwa plastik yang terbentuk masih tetap memiliki sifat hidrofilik seperti komponen penyusunnya. Adanya gugus fungsi seperti $\mathrm{C}-\mathrm{H}$, $\mathrm{C}-\mathrm{NO}_{2},-\mathrm{N}=\mathrm{N},-\left(\mathrm{CH}_{2}\right) \mathrm{n}$, dan $-\mathrm{OH}$, menunjukkan film plastik dapat terdegradasi dengan baik ditanah. Spektroskopi FTIR dan SEM dapat digunakan sebagai instrumen analisis untuk mengklarifikasi kandungan selulosa dan mengamati morfologi selulosa hasil hidrolisa dan bioplastik yang dihasilkan melalui metode casting (Muhaimin 2014).

Bioplastik yang telah dihasilkan masih jauh dari sifat mekanik yang dimiliki plastik sintetis yaitu polipropilen tetapi memiliki kelebihan dapat terurai dengan cepat karena menggunakan polivinil alkohol sebagai bahan utamanya. Aplikasi penelitian ini kedepannya adalah untuk pengembangan kemasan pangan berupa smart packaging dan nanokomposit bioplastik

Tabel 3. Hasil pengujian komposit bioplastik

\begin{tabular}{lcccc}
\hline Perlakuan filler & $\begin{array}{c}\text { TensileStrength } \\
(\mathrm{MPa})\end{array}$ & $\begin{array}{c}\text { TensileModulus } \\
(\mathrm{GPa})\end{array}$ & $\begin{array}{c}\text { Densitas } \\
\left(\mathrm{g} / \mathrm{cm}^{3}\right)\end{array}$ & $\begin{array}{c}\text { Degradation } \\
(\%)\end{array}$ \\
\hline Perlakuan 0\% & 10,08 & 7,1 & 0,13 & $100 \%$ \\
Perlakuan 2\% & 15,72 & 6,3 & 0,13 & $100 \%$ \\
Perlakuan 6\% & 12,75 & 2,9 & 0,06 & $100 \%$ \\
Perlakuan 10\% & 15,34 & 6,7 & 0,04 & $100 \%$ \\
\hline
\end{tabular}

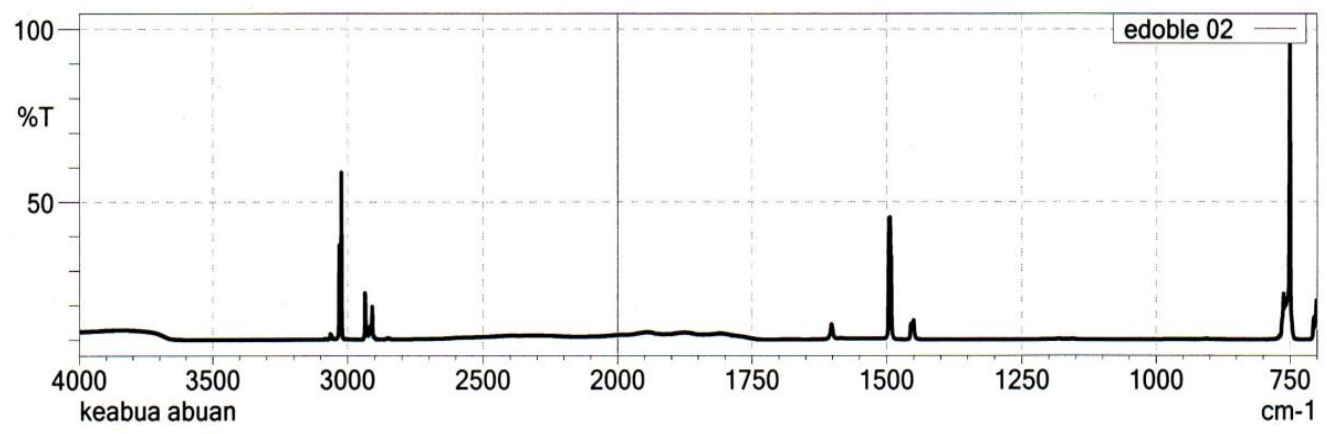

Gambar 6. Hasil pengujian FTIR

\section{KESIMPULAN}

Hasil penelitian sintesis mikro selulosa bakteri dengan metode hidrolisis pada kondisi konsentrasi $\mathrm{HCl} 5 \mathrm{M}$ pada suhu $55^{\circ} \mathrm{C}$ selama 24 jam diperoleh ukuran partikel mikro selulosa bakteri 535,8 nm. Telah diperoleh komposit bioplastik dengan matriks polivinil alkohol dan filler mikro selulosa bakteri dengan komposisi terbaik pada penambahan filler $2 \%$. Nilai kekuatan tariknya $15,72 \mathrm{MPa}$, modulus young 
$16,3 \mathrm{GPa}$, densitas $0,13 \mathrm{~g} / \mathrm{cm}^{3}$, dan degradation $100 \%$.

\section{UCAPAN TERIMAKASIH}

Ucapan terima kasih disampaikan kepada Politeknik ATI Padang dan Pusdiklat Industri, Kementerian Perindustrian yang telah memberikan dana dalam bentuk hibah penelitian.

\section{DAFTAR PUSTAKA}

[ASTM], American Society for Testing and Materials (US). 2002. Standard test methods for tensile properties of plastics, Standard Designation: D 88202.

Abdolmohammadi, S.; Siyamak, S.; Ibrahim, N.A.; Yunus, WMZW.; Rahman, MZA.; Aziz, S.; Fatehi, A. 2012. "Enhancement of Mechanical and Thermal Properties of Polycaprolactone/Chitosan Blend by Calcium Carbonate Nanoparticles." International Journal of Moleculer Sciences 13 (4):4508-4522.

Baek, C.S; Cho, K.H; Ahn, J.W. 2014. "Effect of Grain Size and Replacement Ratio on the Plastic Properties of Precipitation Calcium Carbonat Using Limestone as raw material." Journal of the Korean Ceramic Society 51 (2):127-131.

Bratovčić, A; Odobašić, A; Ćatić, S; Šestan, I. 2015. "Application of polymer nanocomposite materials in food packaging." Croat J. Food Sci. Technol 7 (2):86-94.

Brito, B. S. L.; Pereira, Fabiona V.; Putaux, JeanLuc; Jean, Bruno. 2012. "Preparation, Morphology and Structure of Cellulose Nanocrystals From Bamboo Fibers." Cellulose 19:1527 - 1536.

Darni, Y.; Fathanah, U. 2011. "Pembuatan Plastik Biodegradable dari Campuran Pati Ubi Jalar (Ipomoea Batatas) dan Selulosa Residu Rumput Laut (Eucheuma Spinossum) dengan Gliserol sebagai Plasticizer." Seminar Nasional Hasil Riset dan Standarisasi Industri, Banda Aceh.

Edison, D; Neswati; Rahmi. 2016. Pengaruh Konsentrasi $\mathrm{HCl}$ Dalam Proses Hidrolisis A-Selulosa Dari Ampas Tebu (Saccharum
Officinarum, L.) Terhadap Karakteristik Mikrokristalin.

http://repository.unand.ac.id.

Honavar, Z; Hadian, Z; Mashayekh, M. 2016. "Nanocomposite in food packaging application and their risk assessment for health." Electronic Physician 8 (6):25312538.

Iriani, Evi Savitri; Wahyuningsih, Kendri; Sunarti, Titi Chandra; Permana, Asep W. 2015. "Sintesis Nanoselulosa Dari Serat Nanas dan Aplikasinya Sebagai Pada Film Berbasis Polivinil Alkohol." Jurnal Penelitian Pasca Panen Pertanian 12 (1):11-19.

Jain, KK. 2008. The Handbook of nanomedicine. Basel: Humana Press.

Kakroodi, A.R.; Cheng, S.; Sain, M., Asiri, A. 2014. "Mechanical, Thermal, And Morphological Properties of Nanocomposites Based on Polyvinil Alcohol And Celluloce Nanofiber from Aloe Vera Rind." Journal of Nanomaterials 3.

Kamsiati, Elmi. 2013. "Plastik Ramah Lingkungan." Buletin Inovasi Teknologi Pertanian, 55-56.

Lin, OH; Ishak, ZAM; Akil, HM. 2009. "Preparation and properties of nanosilica-filled polypropylene composites with PP-methyl POSS as compatibiliser." Mater Design 30:748751.

Michael, loelovich. 2012. "Optimal Conditions for Isolation of Nanocrystalline Cellulose Particles." Journal of Nanoscience and Nanotechnology 2 (2):9-13.

Muhaimin, M; Astuti, Wijayanti Dwi; Sosiati, Harini; Triyana, Kuwat. 2014. "Fabrikasi Nanofiber Komposit Nanoselulosa/PVA dengan Metode Electrospinning." Pertemuan IImiah XXVIII HFI Jateng \& DIY, Yogyakarta.

Mulyono, N.; Suhartono, MT.; Angelina, S.; 2015. "Development of Bioplastic Based on Cassava Flour and Its Starch Derrivatives for Food Packaging." Journal of Harmonized Research in Apllied Sciences 3 (2):125-132. 
Oke, Isdin. 2010. "Nanoscience in nature: cellulose nanocrystals." SURG 3 (2):7780.

Roohani, M; Habibi, Y.; Belgacem, YM; Ebrahim, G.; Karimi, A.N.; Dufresne, A. 2008. "Cellulose Whiskers Reinforced Polyvinyl Alcohol Copolymer Nanocomposites." European Polymer Journal 44:2489-2498.

Rosa, M. F.; Medeiros, E. S.; Malmonge, J. A.; Gregorski K. S.; Wood, D. F.; Mattoso, L. H. C.; Glenn, G.; Orts, W. J.; Imam, S. H. 2010. "Cellulose Nanowhiskers From Coconut Husk Fibers: Effect Of Preparation Conditions On Their Thermal And Morphological Behavior." Carbohydrate Polymers 81:83-92.

Sadeghifar, H.; llari, F.; Sarah, P. C.; Dermot F. B.; Dimitris S. A. 2011. "Production Of Cellulose Nanocrystals Using Hydrobromic Acid And Click Reactions On Their Surface. Springer." Journal Material Science 46 (22):7344-7355.

Sanchez, MD.; Lagaron, JM. 2012. "Nanocomposite for food and beverage packaging material." In Nanotechnology in the Food, Beverage and Nutraceutical Industries, edited by Qingrong Huang, 335-361. Woodhead Publishing.

Souza, A.C.; Benze, R.;Ferrao, E.S.; Ditchfield, C.; Coelho, A.C.V.; Tadini, C.C. 2012. "Cassava Starch Biodegradable Films :
Influence of Glycerol and Clay Nanoparticles Content on Tensile and Barrier Properties and Glass Transition Temperature." LWT-Food Science and Technology 46:110-117.

Sultyo, H. W.; Ismiyati. 2012. "Pengaruh Formulasi Pati Singkong-Selulosa Terhadap Sifat Mekanik Dan Hidrofobisitas Pada Pembuatan Bioplastik." Konversi 1 (2):23-30.

Syamsu, Khaswar.; Kuryani, Tutus. 2014. "Pembuatan Biofilm Selulosa Asetat Dari Selulosa Mikrobial Nata De Cassava." E-Jurnal Agroindustri Indonesia 3 (1):126-133.

Utomo, W.A.; Argo, B.D.; Hermanto, M.B. 2013. "Pengaruh Suhu dan Lama Pengeringan Terhadap Karakteristik Fisikokimiawi Plastik Biodegradable dari Komposit Pati Lidah Buaya (Aloe Vera)-Kitosan." Jurnal Bioproses Komoditas Tropis 1 (1).

Wang, N.; Enyong, D.; Rongshi, C. 2008. "Preparation and Liquid Crystalline Properties of Spherical Cellulose Nanocrystals." Langmuir 24:5-8.

Xiong, R.; Xinxing, Z.; Dong, T.; Zehang, Z.; Canhui, L. 2012. "Comparing Microcrystalline With Spherical Nanocrystalline Cellulose From Waste Cotton Fabrics." Cellulose 19:11891198. 